\title{
PENINGKATAN AKTIVITAS DAN HASIL BELAJAR MATEMATIKA STANDAR KOMPETENSI MENERAPKAN KONSEP BARISAN DAN DERET DALAM PEMECAHAN MASALAH MELALUI METODE PEMBELAJARAN DISKUSI KELOMPOK DI KELAS XI AP 3 SEMESTER GANJIL SMKN 1 PAYAKUMBUH TAHUN AJARAN 2015/2016
}

\section{Rinaldi}

\begin{abstract}
Abstrak
Penelitian ini dilakukan bertujuan untuk untuk meningkatkan aktivitas dan hasil belajar Matematika Standar Kompetensi Menerapkan Konsep Barisan dan Deret Dalam Pemecahan Masalah di kelas XI AP 3 semester ganjil Tahun Pelajaran 2015/2016 melalui metode pembelajaran diskusi kelompok. Penelitian tindakan kelas dilaksanakan dalam 3 siklus, yang masing-masing siklus terdiri atas tahap perencanaan, tindakan, observasi dan refleksi. Data yang diperoleh dalam penelitian ini meliputi : hasil belajar siswa yang diambil dari pemberian soal diakhir setiap siklus, aktifitas siswa dalam pembelajaran yang diambil dari lembar observasi. Metode yang digunakan dalam upaya peningkatan aktivitas dan hasil belajar siswa adalah Metode Diskusi Kelompok. Secara umum hasil yang diperoleh dalam penelitian ini dapat diungkapkan bahwa hasil penelitian ini menunjukkan adanya peningkatan nilai hasil belajar siswa. Pada kompetensi dasar sebelumnya rata-rata hitung nilai ulangan harian adalah 69,45 dengan persentase ketuntasan belajar 54,05\% (20 siswa), serta banyak persentase siswa yang tidak tuntas berjumlah 45,95\% (17 siswa) dari 37 orang siswa. Setelah dilakukannya penelitian ini, diharapkan kepada guru untuk dapat menerapkan hasil penelitian ini dalam pembelajaran khususnya pada mata pelajaran Matematika agar pembelajaran menjad lebih efektif dan berkualitas di masa yang akan datang, sehingga output dari pendidikan juga lebih berkualitas.
\end{abstract}

Keyword: Aktivitas Belajar, Hasil Belajar, Diskusi Kelompok, Konsep Barisan Dan Deret, Pemecahan Masalah

Copyright (C) 2016 IICET (Padang - Indonesia) - All Rights Reserved

Indonesian Institute for Counseling, Education and Theraphy (IICET)

\section{PENDAHULUAN}

Pendidikan, ilmu pengetahuan dan teknologi merupakan hal yang sangat penting dalam kehidupan sejak dahulu sampai sekarang, Melalui pendidikan manusia dapat mengembangkan diri maupun memberdayakan potensi alam dan lingkungan untuk kepentingan hidupnya. Usaha untuk meningkatkan diri melalui pendidikan mutlak dilakukan agar tidak ketinggalan dalam percaturan dunia pendidikan.

Matematika merupakan salah satu cabang ilmu pengetahuan yang peranannya dalam pembangunan bangsa tidak diragukan lagi. Peranan ini tidak hanya saja dalam MIPA tetapi juga pada ilmu-ilmu lainnya. Oleh Karena itu dalam mengikuti perkembangan ilmu dan teknologi sekarang ini, kita dituntut untuk mengikuti perkembangan matematika, sebab tidak ada satupun disiplin ilmu yang terlepas dari penggunaan matematika. Melihat pentingnya peranan matematika, pemerintah selalu mengusahakan agar mutu pendidikan semakin baik dari waktu ke waktu. Pemerintah berusaha menyempurnakan kurikulum sesuai dengan perkembangan ilmu dan teknologi. Seperti melengkapi sarana dan prasarana yang di butuhkan para peserta didik dalam menjalani proses pendidikan. Agar kualitas dan kuantitas yang dihasilkan juga semakin baik.

Kita ketahui bahwa dalam proses pembelajaran guru dan siswa terlibat dalam sebuah interaksi dengan bahan pelajaran sesuai mediumnya. Dalam interaksi tersebut siswa diharapkan lebih aktif dan semangat dari pada guru. Apalagi dalam pembelajaran matematika. Dalam pembelajaran matematika siswa diharapkan lebih aktif dalam berbagai hal. Seperti dalam pemecahan soal-soal dan latihan. Pada saat menjawab soal yang diberikan guru pun, terkadang siswa sulit untuk memahami dan menjawabnya. Hal ini terlihat saat guru meminta siswa untuk menjawab soal yang yang ada di papan tulis. Kebanyakan dari siswa 
hanya diam dan tidak berani untuk maju kedepan. Sebagian dari mereka tidak bisa menjawab dan mungkin tidak berusaha menjawabnya. Walaupun ada yang menjawab, mereka tidak mau maju kedepan karena takut jawaban yang mereka berikan salah. Sehingga mereka menunggu teman yang percaya diri untuk menjawab dan membandingkannya. Sedangkan bagi siswa yang tidak bisa menjawab ataupun tidak berusaha menjawab, mereka akan mencontek jawaban temannya atau hanya bisa menunggu dan mencatat jawaban yang di berikan guru.

Selain itu hasil belajar Matematika siswa kelas XI Administrasi Perkantoran 3 ( XIAP3 ) SMK Negeri 1 Payakumbuh berdasarkan informasi dari teman sejawat masih rendah. Siswa masih banyak yang mempunyai nilai di bawah Kriteria Ketuntasan Minimal (KKM) yang telah ditetapkan. Rendahnya hasil belajar matematika siswa dapat terlihat pada hasil Ulangan Harian Matematika siswa kelas XIAP3 Tahun Pelajaran 2015/2016 sebagai berikut:

\section{Tabel 1}

Persentase Hasil Belajar Siswa Kelas XIAP3 Berdasarkan Nilai Ulangan Harian SK Pada Materi Perbandingan Fungsi, Persamaan Identitas Trigonometri dalam Pemecahan Masalah

\begin{tabular}{|c|c|c|c|c|}
\hline No & Jumlah Siswa & $\begin{array}{l}\text { Tuntas } \\
\text { ( Nilai } \geq 70 \text { ) }\end{array}$ & $\begin{array}{l}\text { Tidak Tuntas } \\
(\text { Nilai }<70)\end{array}$ & Nilai rata-rata \\
\hline 1 & 37 siswa & $\begin{array}{ll}20 & \text { orang } \\
(54,05 \%) & \end{array}$ & $\begin{array}{ll}17 & \text { orang } \\
(45,95 \%) & \end{array}$ & 69,46 \\
\hline
\end{tabular}

Berdasarkan tabel di atas terlihat bahwa hasil belajar matematika siswa kelas XIAP3 SMK Negeri 1 Payakumbuh masih rendah. Banyak siswa yang memperoleh nilai yang di bawah Kriteria Ketuntasan Minimal (KKM). Seharusnya pembelajaran dikatakan tuntas apabila mencapai persentase $80 \%$. Kriteria Ketuntasan Minimal siswa kelas XI AP3 Tahun Pelajaran 2015/2016 SMK Negeri 1 Payakumbuh adalah 70. Bila kondisi belajar mengajar seperti ini terus dibiarkan maka akan menyebabkan mutu hasil belajar siswa akan tetap rendah karena pelajaran yang membosankan. Hal ini membuat siswa tidak termotivasi untuk mengikutinya.

Mengingat bahwa SMK merupakan sekolah dibidang kejuruan yang hasil akhir adalah tamatan yang siap bekerja. Oleh karenanya siswa perlu aktif dan berpartisipasi dalam proses pembelajaran agar nantinya akan memberikan hasil yang sesuai dengan yang sudah direncanakan. Khususnya pada Mata Pelajaran Matematika, faktanya bahwa kehidupan kita tidak pernah lepas dari hitungan dan angka-angka. Matematika merupakan materi yang sangat penting di setiap jenjang pendidikan. Buktinya Matematika adalah salah satu materi yang di ujikan secara nasional (Ujian Nasional) guna menentukan tingkat kelulusan siswa, bahkan di perguruan tinggi sekalipun tetap ada perkuliahan Matematika.

Matematika bukan materi yang sulit jika siswa selama proses pembelajaran mampu berkontribusi sepenuhnya dan ditunjang dengan cara, metode, model serta kreatifitas guru mata pelajaran dalam menyajikan materi. Sesuai pengamatan yang telah dilakukan fenomena yang terjadi di kelas menunjukkan bahwa banyaknya siswa yang tidak berkontribusi dalam pembelajaran, sehingga dapat dikatakan bahwa aktivitas belajar siswa rendah. Hal ini dibuktikan dengan rendahnya hasil belajar siswa pada mata pelajaran Matematika. Upaya awal yang sudah dilakukan yaitu dengan memberlakukan sistem poin terhadap siswa yang mau berkontribusi selama pembelajaran. Tetapi hal semacam itu belum mampu meningkatkan aktivitas dan hasil belajar siswa secara menyeluruh.

Berdasarkan kenyataan tersebut, sangat penting bagi guru untuk menerapkan suatu metode pembelajaran yang dapat meningkatkan aktivitas siswa sehingga mutu hasil belajarnya dapat ditingkatkan. Peranan guru sangat penting dalam melaksanakan pengembangan bahan-bahan pengajaran dan alat bantu dalam pembelajaran, serta menggunakan metode yang cocok untuk kelancaran dan terlaksananya proses pembelajaran di Sekolah. Salah satu strategi yang dapat digunakan yaitu dengan menggunakan strategi PAILKEM (Pembelajaran Aktif Inovatif Lingkungan Kreatif Efektif dan Menarik). PAILKEM dikatakan strategi karena bidang garapannya tertuju pada bagaimana cara pengorganisasian pembelajaran, 
menyampaikan atau menggunakan metode pembelajaran dan mengelola pembelajaran (Hamzah:2012). Dalam strategi pembelajaran PAILKEM banyak terdapat model pembelajaran dan salah satuya yaitu Cooperative Learning. Model pembelajaran kooperatif merupakan proses pembelajaran yang dilakukan dengan berkelompok. Menurut teori psikodinamika, kelompok bukan hanya sekadar kumpulan individu melainkan merupakan suatu kesatuan yang memiliki ciri dinamika dan emosional tersendiri. Model pembelajaran kooperatif ini merupakan salah satu model pembelajaran yang dianjurkan oleh para ahli pendidikan untuk digunakan dikarenakan dapat meningkatkan prestasi siwa dan merealisasikan kebutuhan siswa dalam belajar berpikir, memecahkan masalah dan mengintegrasikan ilmu pengetahuan dengan keterampilan. Pembelajaran kooperatif merupakan model pembelajaran yang menggunakan sistem pengelompokan tim kecil.

Cooperative Learning memiliki berbagai tipe metode pembelajaran dan salah satunya yang digunakan yaitu metode diskusi kelompok. Dimana melalui metode ini, siswa dibagi dalam beberapa kelompok dan saling berkontribusi sebagai anggota dalam kelompok. Pada metode pembelajaran ini aktivitas belajar siswa akan meningkat sehingga hasil belajarnya juga akan meningkat. Guru dalam mengajar harus menumbuhkan aktivitas siswa dalam berpikir dan bertindak, dengan aktivitas siswa sendiri, pelajaran menjadi berkesan, dipikirkan, diolah, dan dikeluarkan lagi dalam bentuk yang berbeda, siswa akan bertanya, mengajukan pendapat, menimbulkan diskusi dengan guru. Bila siswa menjadi partisipan aktif maka ia memiliki ilmu pengetahuan dan keterampilan yang baik (Slameto:1991: 87).

Metode pembelajaran diskusi kelompok ini dapat mengembangkan aktivitas siswa dengan membuat kelompok yang terdiri dari 5-6 orang yang akan membentuk pola interaksi yang optimal, mengembangkan semangat kebersamaan, timbulnya motivasi serta menumbuhkan komunikasi yang efektif. Metode pembelajaran ini memberi waktu untuk berfikir bagi siswa sedang dan lambat, sehingga terjadi pembauran antar siswa dalam menyelesaikan persoalan, dan menjadi kebiasaan berbagi pandangan dalam memecahkan suatu masalah.

Berdasarkan latar belakang, maka rumusan masalah penelitian yaitu bagaimanakah peningkatan aktivitas dan hasil belajar Matematika Standar Kompetensi Menerapkan Konsep Barisan Dan Deret Dalam Pemecahan Masalah dapat dilakukan melalui metode pembelajaran diskusi kelompok di kelas XI AP 3 Semester Ganjil SMKN 1 Payakumbuh Tahun Pelajaran 2015/2016. Tujuan penelitian untuk meningkatkan aktivitas dan hasil belajar Matematika Standar Kompetensi Menerapkan Konsep Barisan Dan Deret Dalam Pemecahan Masalah di kelas XI AP 3 semester ganjil Tahun Pelajaran 2015/2016 melalui metode pembelajaran diskusi kelompok.

\section{METODELOGI PENELITIAN}

Penelitian ini adalah Tindakan Kelas (PTK). Penelitian Tindakan Kelas merupakan bentuk penelitian yang dilaksanakan secara lansung oleh guru dalam praktek pembelajaran, dimana guru (peneliti) mengadakan tindakan tertentu berdasarkan masalah-masalah penting di lapangan yang harus segera diatasi. Kelas yang menjadi subjek penelitian adalah kelas XI Program Keahlian Administrasi Perkantoran (XIAP3) Tahun Pelajaran 2015-2016 SMK Negeri 1 Payakumbuh yang berjumlah 37 orang terdiri dari 35 orang perempuan dan 2 orang laki-laki.

Penelitian tindakan ini dilaksanakan selama 17 kali pertemuan terhitung mulai tanggal 28 Juli hingga 01 Oktober 2015 dengan 3 siklus. Siklus pertama dilakukan tiga kali pertemuan ( 3 x 45 menit ), siklus kedua enam kali pertemuan ( 6 × 45 menit ) dan sikus ke tiga tujuh kali pertemuan $(7 \times 45$ menit $)$. Penelitian tindakan kelas ini menggunakan model yang dikembangkan oleh Kemmis dan Mc. Teggart, terdiri dari dua siklus, tiap siklus terdiri atas: perencanaan (plan), pelaksanaan tindakan (action), pengamatan (observation), dan perenungan (reflection).

\section{HASIL DAN PEMBAHASAN PENELITIAN \\ HASIL PENELITIAN \\ Siklus I}

Berdasarkan hasil yang telah dicapai pada siklus I selama 2(dua) kali pertemuan dapat dilihat aktivitas siswa dari tabel dibawah ini: 
Tabel 2

Rekapitulasi Hasil Aktivitas Siswa pada Siklus I

\begin{tabular}{|l|l|l|}
\hline \multirow{2}{*}{ Indikator } & \multicolumn{2}{l|}{ Pertemuan } \\
\cline { 2 - 3 } & I & II \\
\hline A & $59,46 \%$ & $62,16 \%$ \\
\hline B & $45,95 \%$ & $48,65 \%$ \\
\hline C & $27,03 \%$ & $27,03 \%$ \\
\hline D & $48,65 \%$ & $59,46 \%$ \\
\hline E & $54,05 \%$ & $62,16 \%$ \\
\hline F & $56,76 \%$ & $62,16 \%$ \\
\hline G & $59,46 \%$ & $64,86 \%$ \\
\hline H & $59,46 \%$ & $62,16 \%$ \\
\hline
\end{tabular}

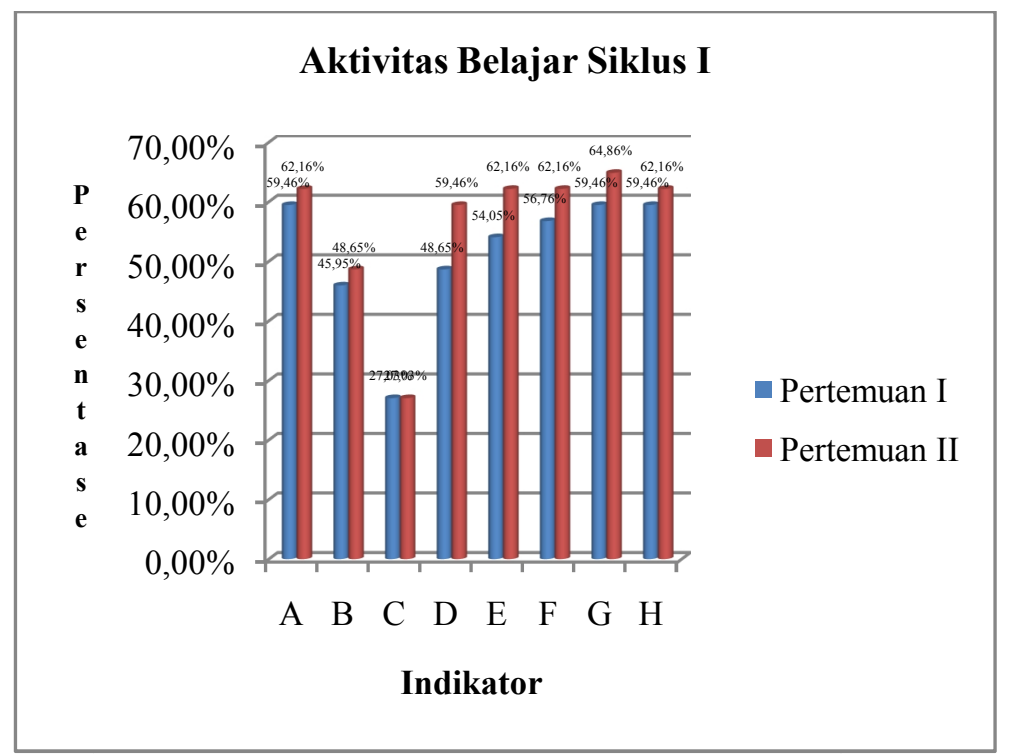

Dari grafik di atas terlihat bahwa aktivitas siswa membaur/mengkondisikan diri dalam kelompok masih sedikit walaupun persentase telah mengalami peningkatan di pertemuan kedua dari 45,95 \% meningkat menjadi 48,65\%. Kategori mengerjakan tugas secara antusias/fokus masih sangat sedikit (27,03\%), pada pertemuan kedua masih berada dalam kategori sangat sedikit (27,03\%).

Hasil belajar siswa yang dilihat dari penilaian proses dan tes. 
Tabel 4

Perolehan Hasil belajar Siswa pada Siklus I

\begin{tabular}{|l|l|l|}
\hline Kriteria & Sebelum & Sesudah \\
\hline Tuntas & $54,05 \%$ & $69,44 \%$ \\
\hline Tidak Tuntas & $45,95 \%$ & $30,56 \%$ \\
\hline
\end{tabular}

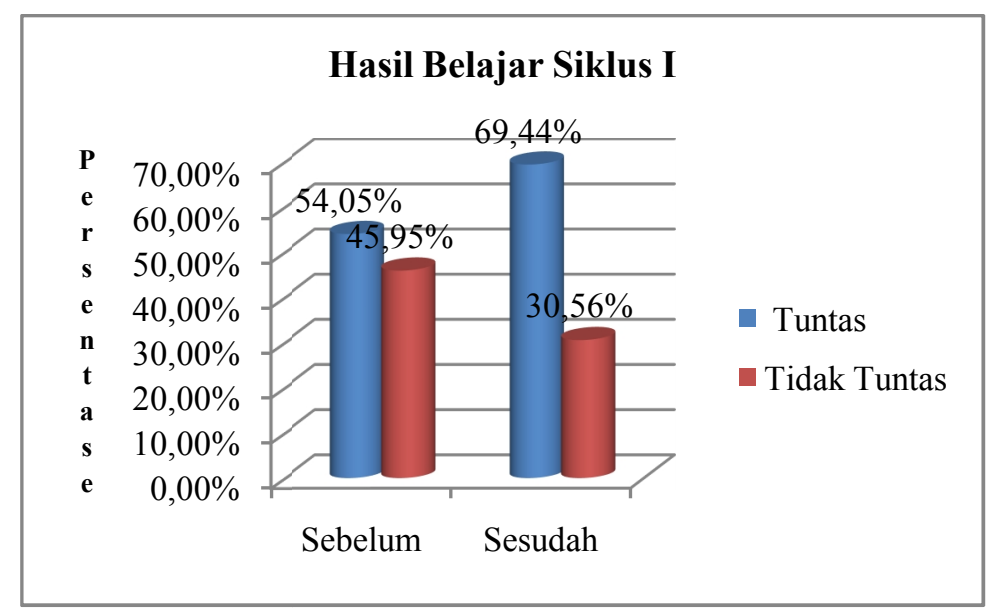

Dari data tabel hasil belajar diatas masih terdapat 25 (dua puluh lima ) orang siswa pada pertemuan pertama yang nilai prosesnya dibawah KKM Matematika yaitu sebesar 78 (tujuh puluh delapan), juga dari hasil tes siklus I, ditemukan siswa yang dibawah KKM sebanyak 11 orang $(30,56 \%)$ dengan nilai rata-rata 80,11 .

Berdasarkan data di atas, pada siklus I masih ditemui beberapa kelemahan-kelemahan pada aktivitas siswa. Aktivitas siswa bersosialisasi dalam kelompok masih sedikit walaupun persentase telah mengalami peningkatan di pertemuan kedua dari 45,95\% meningkat keangka 48,65\%. Kategori mengerjakan tugas secara antusias/fokus masih sangat sedikit (27,03\%). Dari hasil belajar siswa masih terdapat 25 (dua puluh lima) orang siswa pada pertemuan pertama masih dibawah KKM Matematika yaitu sebesar 78 (tujuh puluh delapan) dan hasil tes siklus I. Temuan pada Siklus I tedapat hasil yang kurang memuaskan yaitu dari segi:

1. Mengkondisikan diri dalam kelompok

2. Mengerjakan tugas secara bersungguh-sungguh

3. Hasil belajar diakhir PBM masih kurang

\section{Siklus II}

Aktivitas Belajar siswa pada siklus II dapat dilihat pada table berikut ini.

Tabel 5.

Rekapitulasi Hasil Aktivitas Siswa pada Siklus II

\begin{tabular}{|l|l|l|l|l|l|}
\hline \multirow{2}{*}{ Indikator } & \multicolumn{3}{|l|}{ Pertemuan } & \multicolumn{4}{|l|}{} \\
\cline { 2 - 6 } & III & IV & V & VI & VII \\
\hline A & $72,22 \%$ & $78,38 \%$ & $81,08 \%$ & $82,86 \%$ & $83,33 \%$ \\
\hline B & $47,22 \%$ & $43,24 \%$ & $64,86 \%$ & $62,86 \%$ & $47,22 \%$ \\
\hline
\end{tabular}




\begin{tabular}{|l|l|l|l|l|l|}
$\mathrm{C}$ & $41,67 \%$ & $45,95 \%$ & $48,65 \%$ & $51,43 \%$ & $52,78 \%$ \\
\hline $\mathrm{D}$ & $63,89 \%$ & $67,57 \%$ & $72,97 \%$ & $74,29 \%$ & $77,78 \%$ \\
\hline $\mathrm{E}$ & $69,44 \%$ & $67,57 \%$ & $70,27 \%$ & $71,43 \%$ & $75,00 \%$ \\
\hline $\mathrm{F}$ & $69,67 \%$ & $67,57 \%$ & $70,27 \%$ & $71,43 \%$ & $72,22 \%$ \\
\hline $\mathrm{G}$ & $69,44 \%$ & $70,22 \%$ & $72,97 \%$ & $71,43 \%$ & $77,78 \%$ \\
\hline $\mathrm{H}$ & $69,44 \%$ & $72,97 \%$ & $75,68 \%$ & $71,43 \%$ & $75,00 \%$ \\
\hline
\end{tabular}

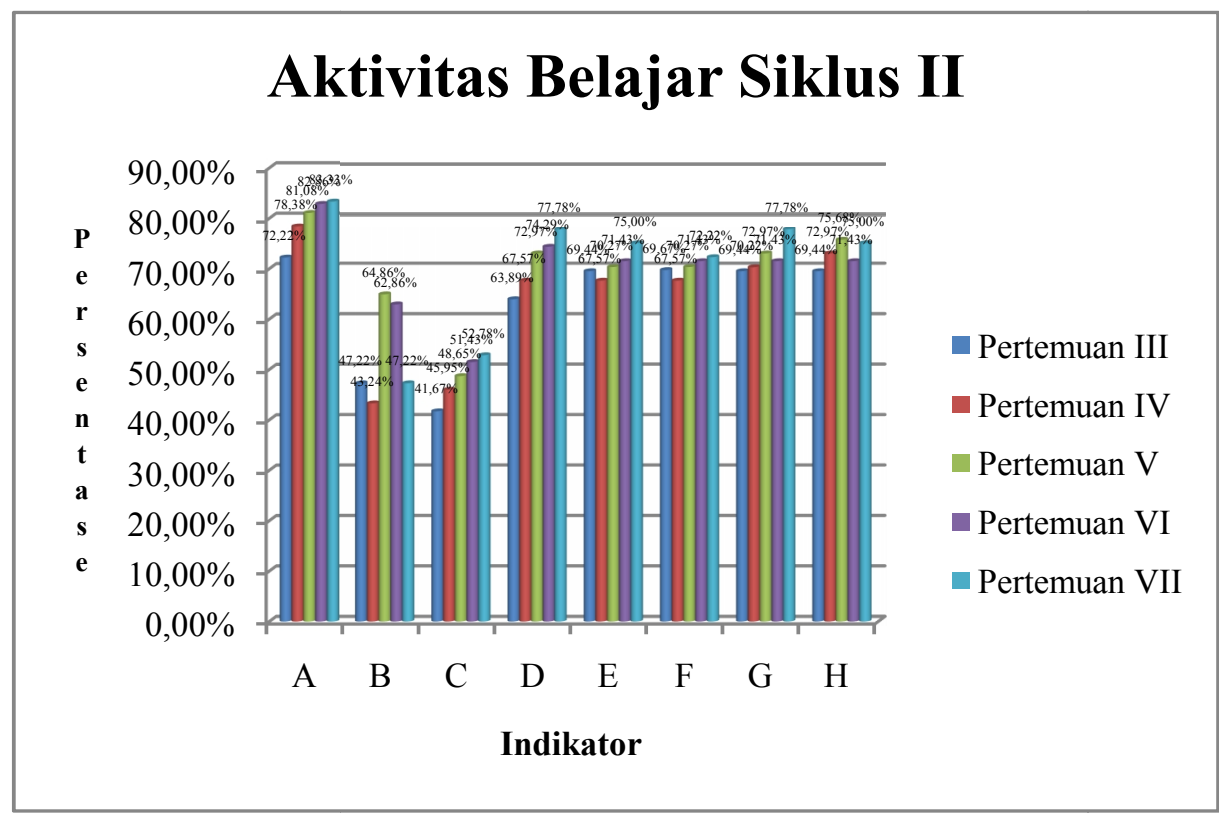

Tabel dan grafik di atas menunjukkan bahwa aktivitas siswa bersosialisasi dalam kelompok masih sedikit dengan persentase akhir sebesar 47,22\%. Kategori aktivitas belajar siswa untuk mengerjakan tugas secara antusias/fokus telah mengalami peningkatan sebesar 52,78\%.

Hasil belajar siswa pada siklus II dapat dilihat pada table berikut ini.

\section{Tabel 6}

Perolehan Hasis belajar Siswa pada Siklus II

\begin{tabular}{|l|l|l|}
\hline Kriteria & Siklus I & Sesudah \\
\hline Tuntas & $69,44 \%$ & $83,88 \%$ \\
\hline Tidak Tuntas & $30,56 \%$ & $16,67 \%$ \\
\hline
\end{tabular}


Gambar 4.

Hasil Belajar Pada Siklus II

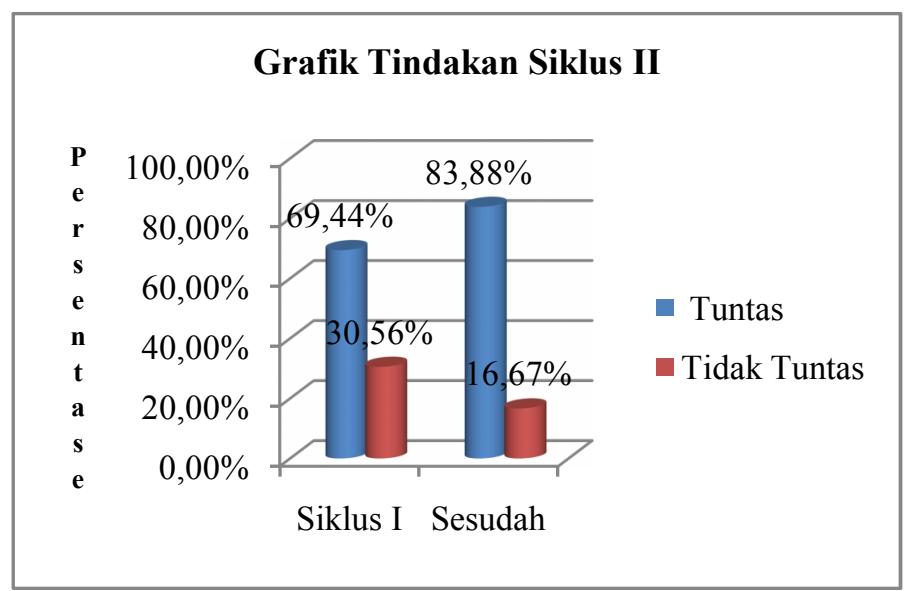

Dari data tabel hasil belajar diatas masih terdapat 24 (dua puluh empat) orang siswa yang nilai tesnya masih dibawah KKM Matematika yaitu sebesar 74 (tujuh puluh empat). Hasil belajar siswa jika dibanding pada siklus ke 1 telah terjadi peningkatan rata-rata nilai tes hasil belajar menjadi 80,67.

Pada siklus II aktivitas siswa bersosialisai serta mengkondisikan diri dalam kelompok masih belum maksimal tapi sudah mengalami peningkatan. Hasil belajar mengalami peningkatan dari nilai rata-rata pada siklus I sebesar 80,11 menjadi 80,67 disiklus II. Pembelajaran pada siklus II masih memiliki kelemahan sebagai berikut.

1.Mengkondisikan diri dalam kelompok

2.Mengerjakan tugas secara bersungguh-sungguh

3.Hasil belajar diakhir PBM masih kurang

\section{Siklus III}

Aktivitas Belajar siswa pada siklus III dapat dilihat pada tabel berikut ini.

Tabel 7

Rekapitulasi Hasil Aktivitas Siswa pada Siklus III

\begin{tabular}{|l|l|l|l|l|l|l|}
\hline \multirow{2}{*}{ Indikator } & \multicolumn{2}{|l|}{ Pertemuan } & XX & X & XI & XII \\
\cline { 2 - 7 } & VIII & & $94,59 \%$ & $97,22 \%$ & $97,22 \%$ & $100 \%$ \\
\hline A & $91,67 \%$ & $94,44 \%$ & & & & \\
\hline B & $58,33 \%$ & $63,89 \%$ & $64,86 \%$ & $63,89 \%$ & $66,67 \%$ & $72,29 \%$ \\
\hline C & $58,33 \%$ & $63,89 \%$ & $62,16 \%$ & $72,22 \%$ & $75,00 \%$ & $82,86 \%$ \\
\hline D & $77,87 \%$ & $80,56 \%$ & $81,08 \%$ & $80,56 \%$ & $80,56 \%$ & $80,00 \%$ \\
\hline E & $83,33 \%$ & $86,11 \%$ & $86,49 \%$ & $86,11 \%$ & $86,11 \%$ & $82,86 \%$ \\
\hline G & $72,22 \%$ & $75,00 \%$ & $75,68 \%$ & $75,00 \%$ & $77,78 \%$ & $80,00 \%$ \\
\hline H & $80,56 \%$ & $83,33 \%$ & $81,08 \%$ & $91,67 \%$ & $91,67 \%$ & $91,43 \%$ \\
\hline
\end{tabular}




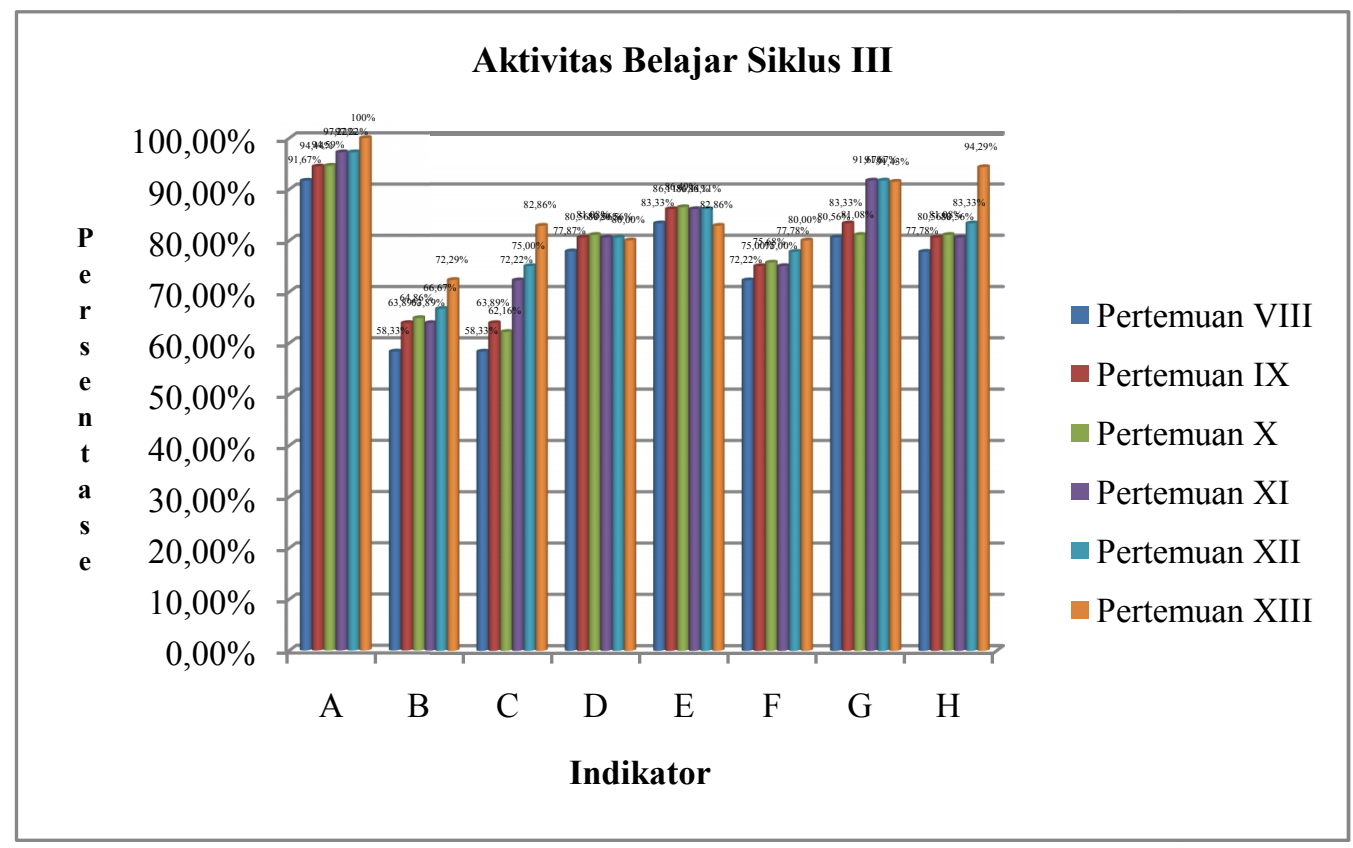

Dari tabel di atas diketahui bahwa aktivitas siswa bersosialisasi dalam kelompok telah meningkat menjadi 74,29\%. Kategori aktivitas belajar siswa untuk mengerjakan tugas secara antusias/fokus telah mengalami peningkatan menjadi 82,86\%. Hasil belajar siswa dapat dilihat pada tabel berikut ini.

Tabel 8

Perolehan Hasil belajar Siswa pada Siklus III

\begin{tabular}{|l|l|l|}
\hline Kriteria & Siklus II & Sesudah \\
\hline Tuntas & $83,33 \%$ & $88,57 \%$ \\
\hline Tidak Tuntas & $16,67 \%$ & $11,11 \%$ \\
\hline
\end{tabular}

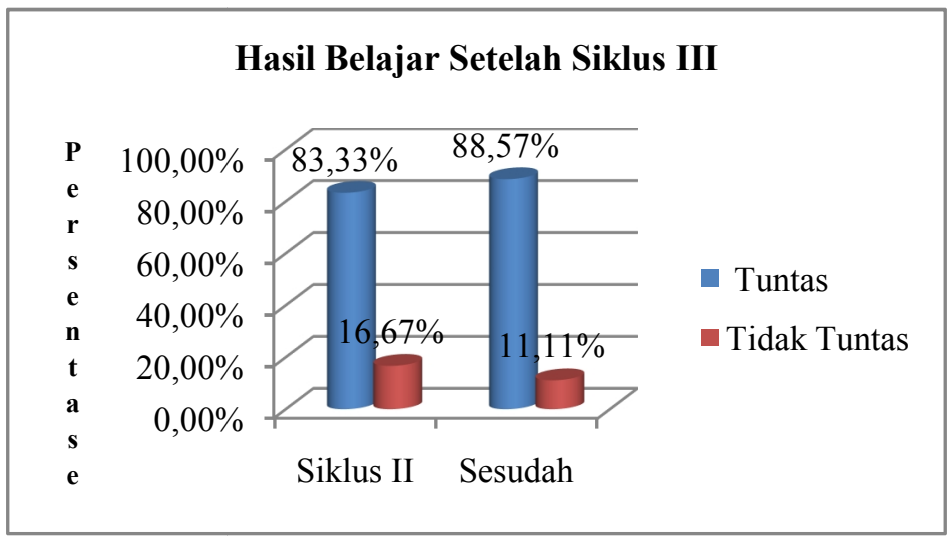


Tabel hasil belajar di atas menunjukkan bahwa terjadinya peningkatan hasil belajar siswa dengan rata-rata 81,91. Pada siklus ini ditemukan siswa yang dibawah KKM sebanyak 6 orang ( 16,67\%).

Pada siklus ke III aktivitas belajar siswa dalam kelompoknya telah mengalami peningkatan sebesar $74,29 \%$. Kategori aktivitas belajar siswa untuk mengerjakan tugas secara antusias/fokus telah mengalami peningkatan sebesar $82,86 \%$. Hasil belajar siswa mengalami peningkatan.

\section{PEMBAHASAN}

Hasil observasi diketahui bahwa terjadinya peningkatan aktivitas siswa dalam proses pembelajaran Matematika. Menurut Hartono (2008:5) "Aktivitas adalah suatu kesibukan dalam kelas secara terstruktur dan terbimbing oleh guru guna meningkatkan pemahaman siswa terhadap pelajaran yang disajikan". Metode pembelajaran diskusi kelompok dapat memotivasi siswa berperan aktif dalam dalam pembelajaran. Penerapan metode diskusi kelompok ini dapat meningkatkan interaksi antar siswa, siswa bekerjasama dalam mempelajari materi juga tugas-tugas yang diberikan guru. Pada akhirnya siswa dapat mempelajari sesuatu dari pembelajaran yang dilaksanakan. Belajar dapat diartikan sebagai proses perubahan perilaku, akibat interaksi individu dengan lingkungan (Muhammad, Ali:2008).

Diskusi kelompok telah menjadikan siswa saling membantu satu sama lain, menghargai pendapat temannya, berani mengeluarkan pendapat, memjelaskan dan mempertahankan pendapat. Suasana belajar yang demikian menumbuhkan sikap percaya diri siswa, saling menghargai dan bekerja sama. Diskusi kelompok dan diskusi kelas meningkatkan motivasi siswa untuk bertanya, menanggapi dan mengeluarkan pendapat, sehingga menjadikan siswa berfikir secara kritis dan mampu meningkatkan penguasan siswa terhadap materi pelajaran. Hal ini merupakan pembelajaran aktif. Hal ini sesuai pendapat Agus, Suprijono (2010) bahwa pembelajaran aktif harus menumbuhkan suasana aktif bertanya, mempertanyakan, dan mengemukakan gagasan.

Sesuai dengan pencapaian indikator kriteria keberhasilan dalam penelitian ini yaitu sebagai berikut :

$>$ Adanya perubahan proses pembelajaran kearah yang lebih baik, yakni dengan nilai rata-rata siswa mencapai 75,00. Target ini telah dicapai ditandai dengan nilai hasil belajar siswa telah mengalami peningkatan dari 8011 disiklus I menjadi 80,67 disiklus II serta meningkat rerataanya diangka 81,91 disiklus III.

$>$ Terdapat perubahan nilai berupa peningkatan dari nilai sebelumnya yakni sekitar $75 \%$ siswa XIAP3 mendapatkan nilai di atas 75, target ini telah dicapai dimana sebelum tindakan ini jumlah siswa yang mendapatkan nilai diatas 75 hanya 54,05\%, telah meningkat menjadi 89,19\% setelah dilakukan Ulangan Tengah Semester (UTS) diakhir pelaksanaan penelitian ini.

$>$ Dari pengamatan, aktivitas siswa XIAP3 meningkat dengan menggunakan model pembelajaran diskusi kelompok dan tutor teman sebaya ini yakni dengan keaktifan siswa secara keseluruhan telah mencapai angka $75 \%$, secara bertahap yang dapat dilihat dari tabel berikut ini

Tabel 9

Rata - rata Aktivitas Belajar Siswa Siklus I, II dan III

\begin{tabular}{|l|l|l|l|}
\hline \multirow{2}{*}{ Indikator } & \multicolumn{3}{|c|}{ Siklus } \\
\cline { 2 - 4 } & Siklus I & Siklus II & Siklus III \\
\hline A & 60,81 & 79,57 & 95,86 \\
\hline B & 47,3 & 53,08 & 65,32 \\
\hline C & 27,03 & 48,09 & 69,08 \\
\hline D & 54,05 & 71,3 & 80,09 \\
\hline E & 58,11 & 70,74 & 85,17 \\
\hline F & 59,46 & 69,63 & 75,95 \\
\hline
\end{tabular}




\begin{tabular}{|l|l|l|l|}
$\mathrm{G}$ & 62,16 & 72,38 & 86,62 \\
\hline $\mathrm{H}$ & 60,81 & 72,9 & 82,93 \\
\hline
\end{tabular}

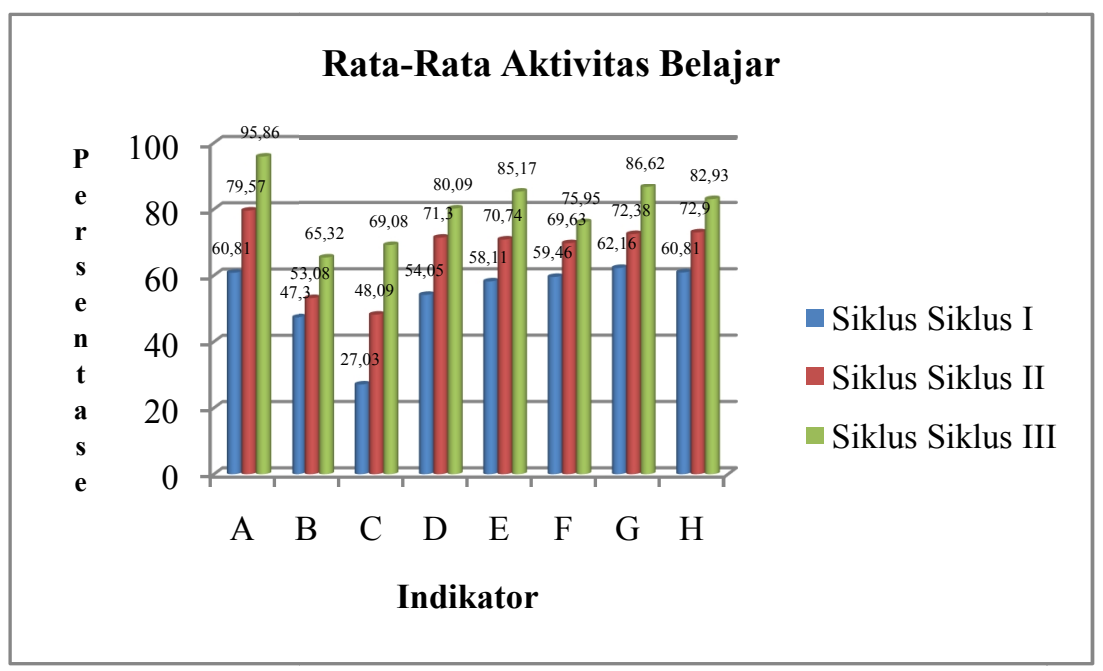

Dari tabel diatas diketahui bahwa aktivitas memperhatikan uraian guru mulai dari siklus ke 1 dengan rerataan persentasenya mulai dari $60,81 \%$, menjadi $79,57 \%$ siklus II serta pada siklus III $100 \%$, seterusnya aktivitas siswa mengkondisikan diri didalam kelompoknya dari tiga belas kali pertemuan diperoleh rerataan persentase nya 47,30 \% disiklus I, 53,08\% di siklus II serta 65,32\% disiklus III,aktivitas antusias mengerjakan tugas persentasenya dimulai dari siklus I sebesar $27,03 \%$, siklus II sebesar $48,09 \%$, dan $69,08 \%$ pada siklus III ,aktivitas siswa bekerjasama dalam diskusi angka yang diperoleh cukup baik yaitu dimulai dari siklus I,II dan III dengan perolehan rerataan persentasenya 54,05\% siklus I, 71,30\% siklus II, dan 80,09\% siklus III. Aktifitas memberikan respon positif atas jawaban temannya rerataan persentasenya naik persiklus dimulai pada angka persentase $58,11 \%$ disiklus pertama,70,74\% pada siklus II, naik lagi keangka $85,17 \%$ disiklus III. Aktifitas mengerjakan evaluasi secara jujur,pada siklus pertama 59,46\%,94\% disiklus kedua 69,63\% disiklus ketiga, 75,95\%, hasil yang cukup mengembirakan. Aktifitas memberikan masukan dan berpartisipasi didalam diskusi dikelompoknya dari siklus pertama sampai ke tiga persentasenya $62,16 \%$, lalu $72,38 \%$, dan $86,62 \%$. Aktifitas terakir yang dilihat dalampenelitian ini adalah aktifitas aktif dalam kelompok diskusi/jadi presentasi dikelompoknya/tutor teman sebaya dari siklus pertama sampai siklus ketiga persentasenya dimulai dari angka $60,81 \%$, kemudian $72,90 \%$, dan $82,93 \%$.

Melihat dari tiga kriteria indikator keberhasilan penelitian ini, ketiganya telah dicapai yaitu nilai rata-rata serta ketuntasan hasil belajar, yang belum tercapai keaangka $75 \%$ yaitu aktivitas mengkondisikan diri dikelompoknya, serta antusias dalam mengerjakan tugas, dua dari delapan aktivitas yang diamati, maka dari itu penulis merekomendasikan metode diskusi kelompok dan tutor teman sebaya dapat dipergunakan dalam pembelajaran Matematika pada Standar Kompetensi Menerapkan konsep barisan dan deret dalam pemecahan masalah.

Pada kenyataannya jika aktivitas siswa meningkat, maka hasil belajar siswa juga mengalami peningkatan. Hasil belajar pada hakikatnya adalah perubahan tingkah laku pada diri seseorang. Tingkah laku sebagai hasil belajar dalam pengertian luas mencakup bidang kognitif, afektif, dan psikomotor (Sudjana:1997:3) 
Tabel 10

Rata-Rata Hasil Belajar Siklus I, II dan III

\begin{tabular}{|l|l|l|l|}
\hline Kriteria & Siklus I & Siklus II & Siklus III \\
\hline Tuntas & $69,44 \%$ & $83,33 \%$ & $88,57 \%$ \\
\hline Tidak Tuntas & $30,56 \%$ & $16,67 \%$ & $11,11 \%$ \\
\hline
\end{tabular}

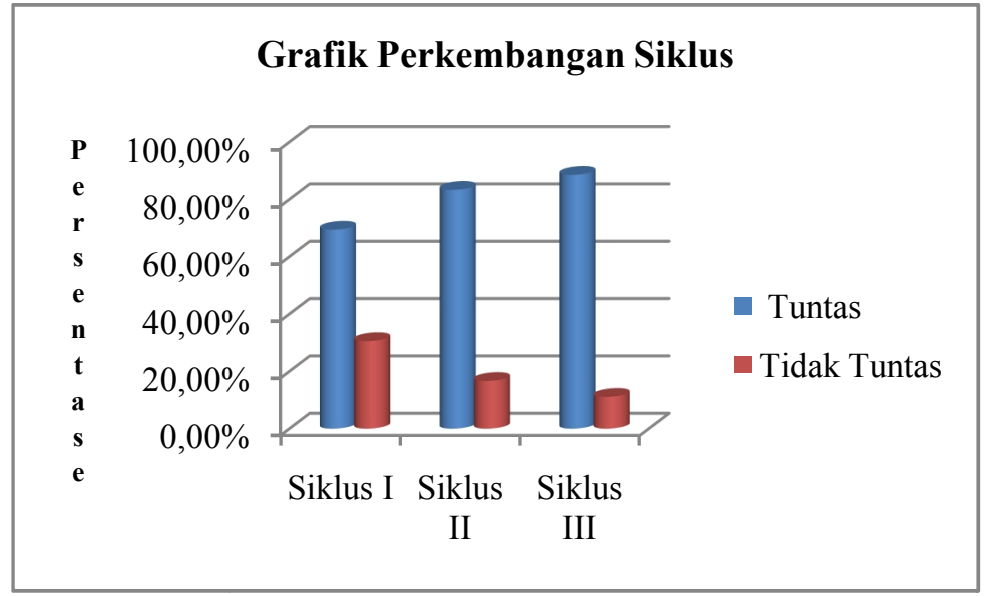

\section{KESIMPULAN DAN SARAN \\ KESIMPULAN}

Hasil analisa data yang diperoleh dari penelitian ini dapat disimpulkan bahwa penggunaan metode Diskusi Kelompok dapat menciptakan belajar Matematika yang menyenangkan yang bermuara pada peningkatan hasil belajar siswa. Keberhasilan tersebut dapat dilihat dari adanya indikasi peningkatan hasil belajar dan keaktifan aktivitas siswa dalam belajar.

\section{SARAN}

1. Guru harus dapat memilih materi yang tepat dengan menggunakan metode diskusi kelompok.

2. Guru harus memperhatikan minat belajar siswa dan kemampuan awal (entry behavior) siswa.

\section{DAFTAR PUSTAKA}

Agus, Suprijono. 2010. Cooperative Learning. Jakarta: CTSD.

Hamzah, B. Uno dan Nurdin Mohammad.2012. Belajar dengan Pendekatan PAILKEM. Jakarta: Bumi Aksara.

Hartono. 2008. PAIKEM Pembelajaran Aktif, Inovatif, Kreatif, Efektif, dan Menyenangkan. Pekanbaru: Zanafa.

Muhammad, Ali. 2008. Guru dalam Proses Belajar Mengajar. Bandung: Sinar Baru Algensindo.

Slameto. 1991. Belajar Dan Faktor Yang Mempengaruhinya. Jakarta:Rineka : Rineka Cipta.

Sudjana, Nana. 1997. Belajar dan Faktor yang Mempengaruhinya. Bandung : CV. Sinar Baru. 